\title{
THE POWER OF PROPHECY
}




\section{Dedication}

For the family and descendants of Pangéran Dipanagara In honour and respect

'You alone are the means, but that not for long, only to be counted amongst the ancestors.'

Parangkusuma prophecy, circa 1805

'History says:

“Don't hope on this side of the grave.

But then once in a lifetime,

The longed for tidal wave of justice can rise up And hope and history rhyme."

So hope for a great sea change,

On the far side of revenge.

Believe that a further shore

Is reachable from here.'

Seamus Heaney

Cover illustrations:

Eruption of Mount Merapi, painted by Radèn Sarif Salèh in 1865

(Photograph by courtesy of the Rijksmuseum van Geologie en Mineralogie,

Leiden)

Dipanagara during the Java War (1825-1830)

Herman Willem Daendels (Photograph by courtesy of the Iconografisch

Bureau, The Hague) 
V E R H A N D E L I N G E N VAN HET KONINKLIJK INSTITUUT VOOR TAAL-, LAND- EN VOLKENKUNDE

249

\section{PETER CAREY}

\section{THE POWER OF PROPHECY \\ Prince Dipanagara and the end of an old order in Java, 1785-1855}

Second edition

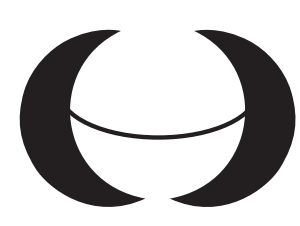

KITLV Press

Leiden

2008 
Published by:

KITLV Press

Koninklijk Instituut voor Taal-, Land- en Volkenkunde

Royal Netherlands Institute of Southeast Asian and Caribbean Studies

PO Box 9515

2300 RA Leiden

The Netherlands

website: www.kitlv.nl

e-mail: kitlvpress@kitlv.nl

KITLV is an institute of the Royal Netherlands Academy of Arts and Sciences (KNAW)

First published in November 2007

Cover: Creja ontwerpen, Leiderdorp

ISBN 9789067183031

(C) 2007 Koninklijk Instituut voor Taal-, Land- en Volkenkunde

No part of this publication may be reproduced or transmitted in any form or by any means, electronic or mechanical, including photocopy, recording, or any information storage and retrieval system, without permission from the copyright owner.

Printed in the Netherlands 


\section{Contents}

Preface $\quad x i$

Abbreviations $\quad$ xxiii

$\begin{array}{ll}\text { Maps of eastern and central Java } & \text { XxV }\end{array}$

I The south-central Javanese world, circa 1792-1825 1

The 'Versailles of Java': Yogya in the early nineteenth century 1

The Yogya military establishment 5

The landed base of the military establishment 8

The royal apanage system 9

The role of the tax collectors 14

The western mancanagara: Banyumas 19

The western nagara agung: Bagelèn 23

Social groups and the village community 27

The golden age of the sikep? 33

Extension of ricefields and development of irrigation 35

Demographic growth, 1755-1825 39

Public health 41

Diet and peasant lifestyles 43

Early marriage and the value of children 46

Rural criminality, social bandits and fighting cocks 47

The forces of law and order 53

The Yogya taxation system and the eastern outlying districts 56

The pancas revisions of the second sultan and their impact 60

Conclusion 66

II Dipanagara's youth and upbringing, 1785-1803

A prophetic birth 69 
Female relatives and influences 71

A Tegalreja childhood 80

Inheriting the Tegalreja estate 83

The Tegalreja circle; early contacts with the Islamic communities 88

Conclusion 94

III Young manhood: Marriage, education, and links with the santri community, 1803-1805

First marriage and development of the Tegalreja community 97

Education and literary interests 102

Character, intellectual ability and relations with Europeans 105

Understanding of Islam 110

Appearance, personality, family and pleasures 115

Conclusion 124

IV Pilgrimage to the south coast, circa 1805

Lelana: spiritual wanderings as rite de passage 127

Preparations for a pilgrimage 128

Tirakat: solitary withdrawal and first visions 131

At the south coast: meetings with Ratu Kidul 137

Final instruction at Parangkusuma and return to Tegalreja 150

Conclusion 155

$\mathrm{V}$ The beginning of the ruin of the Land of Java: Yogyakarta and

Daendels' new order, 1808

Daendels' new order 157

Plans for annexation of territory in central and east Java 161

Daendels' edicts on ceremonial and etiquette and their impact 166

Military manoeuvres; Javanese and Dutch 175

The emergence of an anti-Dutch party in Yogya 187

The Javanese buffalo confronts the Dutch tiger 194

Conclusion 201

VI The old order's last champion: The origins and course of Radèn Rongga's rebellion, 1809-1810

The despoliation of Yogya 205

Military preparations and Daendels' July 1809 visit 207 
The struggle over the teak trade and the crisis in the eastern mancanagara and pasisir 211

The scapegoating of Radèn Rongga 218

The April-August 1810 crisis in Dutch-Yogya relations 222

The 'piling up' of affairs and preparations for

Rongga's rebellion 230

Cleansing Java of defilement; Radèn Rongga's eastern mancanagara rebellion 242

Conclusion 258

VII The end of the beginning; the last months of the Franco-Dutch government and the British rape of Yogyakarta, 1811-1812

Introduction 261

The reckoning 262

Incipient civil war in Yogya 271

The collapse of the Franco-Dutch government 275

The squaring of accounts 287

The British attempt at compromise and Raffles' first visit to the courts 297

Preparations for war 312

The fall of Yogyakarta, 20 June 1812331

Conclusion 342

VIII Into a new era: The British interregnum, 1812-1816

Lineaments of a new order 345

The plunder of the Yogya kraton 346

The appointment of Hamengkubuwana III and kasepuhan-karajan rivalries 352

Creation of the Pakualaman, exile of the old sultan and the disposal of kraton plunder 359

The third sultan's new order and Dipanagara's role 365

The 1 August 1812 treaties and their implications 377

Positive developments during the third sultan's reign 389

Political and administrative changes 394

Dipanagara's second marriage and the death of the third sultan 401

Accession, regency and marriage of the boy sultan, Hamengkubuwana IV 408

The Sayyid Kramat disturbance in Madiun and the sepoy plot of 1815414

Conclusion 428 
IX Binding on the iron yoke: The returned Dutch administration, the impoverishment of the south-central Javanese peasantry and the rise of millenarian expectations, 1816-1822

Squaring the circle 431

A Resident who enjoyed eating and drinking and the spreading of Dutch ways 435

The early challenges of Nahuys' Residency 441

Nahuys' land-rent initiative in the Principalities and its problems 454

Raffles' land tax, coffee plantations and the situation in Kedhu 464

The working of the tollgates 467

The impact of the tollgates on internal trade and Sino-Javanese relations 471

The effects of the opium monopoly 478

Popular millenarian movements and prophecies in south-central Java 480

The crisis in the Javanese countryside; the cholera epidemic of 1821 and Pangéran Dipasana's revolt 493

Events at the courts in the last years of Pakubuwana IV and Hamengkubuwana IV's reigns 499

Conclusion 503

$X \quad$ Waiting for the 'Just King': The road to war in south-central Java, 1822-1825

The man of destiny 505

The aftermath of the fourth sultan's death and Dipanagara's guardianship 506

The December 1822 eruption of Mountt Merapi and the Jayabaya prophecies 512

A small, fat and shy man: Yogyakarta's new Resident 517

The abolition of the land-rent and its consequences 527

Dipanagara's role as guardian and the land-rent indemnities 537

Dipanagara's break with the court 543

The moral rot: Danureja's rule and the conduct of senior Dutch officials in Yogya 546

The government's annexation plans and their impact 553

Dipanagara's pre-war visions 564

Dipanagara's understanding of his role as a Javanese Just King and his attitude towards the Europeans in Java 583 Preparations for rebellion 591 
The outbreak of the Java War 597

Conclusion 602

XI The last stand of the old order: reflections on the Java War,

1825-1830

605

Introduction 605

Mobilization for war: finance, peasant manpower and armaments 606

The role of women 613

Xenophobia and identity: changing attitudes towards the

Chinese and issues of Javanese language and culture 617

Leadership and regional loyalties 621

The role of the santri communities 626

Satria and santri: the breakdown in relations between

Dipanagara and Kyai Maja 629

Dutch military and political tactics 639

Dipanagara's fiscal regime: Senthot and the problems of dwifungsi 647

Conclusion 653

XII Enduring the unendurable: Dipanagara's capture at

Magelang and exile in Sulawesi, 1830-1855

Part One: The road to Magelang and Batavia

Introduction 657

The colonel's promise: Dipanagara's negotiations with

Cleerens in February 1830 and the question of safe conduct 660

Treachery or honourable submission? Dipanagara's arrest at Magelang, 28 March 1830677

Steamboat to Batavia: how Dipanagara received the governor-general's life sentence 699

Part Two: The sultan over the water

The Radeau de Méduse: surviving the corvette 'Pollux', 3 May-12 June 1830713

A Minahasan interlude: Dipanagara's Manado years, 1830-1833 721

Closing the circle: the state prisoner of Fort Rotterdam, Makasar, 1833-1855 734

Conclusion 756 


\section{Appendices}

I Family tree of the Yogyakarta sultanate 760

II Family tree illustrating the connections between

Dipanagara and the Danurejan

III Family tree illustrating the connections between Dipanagara and the Prawiradirjan

IV Pangéran Dipanagara's wives, family and children

Va Chief ministers (patih) of Yogyakarta and Surakarta, 1755-1847 770

$\mathrm{Vb}$ Major officials of the Yogyakarta administration, 1755-1825 772

VI List of country estates/rural retreats (pesanggrahan), hunting lodges and pleasure gardens (kelangenan-Dalem) built in Yogyakarta by the first four sultans, 1755-1822

VIIa List of religious boarding schools (pesantrèn, pondhok), centres for scholars learned in figh law (pathok negari) and tax-free areas set aside for men of religion and keepers of royal gravesites (pradikan, pamutihan, jurukuncèn) in Yogyakarta pre-1832

VIIb List of kyai, haji and religious officials associated with Dipanagara

VIII List of princes (pangéran) and senior officials (priyayi) of the Yogyakarta kraton showing landholdings and pensions, 1808-1820, and allegiance during the Java War

IX Major officials of the Dutch East Indies Company, the British interim administration, and the Netherlands Indies government, 1780-1856

$X \quad$ Rice prices in Yogyakarta (1804-1826) and throughout Java (1817-1825)

XI List of Dipanagara's heirloom (pusaka) weapons

XII List of Dipanagara's followers in Manado, June 1830-June 1833816

XIII Letters written by Dipanagara from Batavia (1830) and Makasar (1837)

XIV Javanese and Western chronology, AD 1785-1855 828

XV Revenue returns from the tollgate, opium and other tax farms in Yogyakarta, 1808-1825

XVI Comparative values of paper and metal currency circulating in Java in 1811 


\section{Preface}

The Java War (1825-1830) was a watershed in the history of Java and of all Indonesia. ${ }^{1}$ For the first time a European colonial government faced a social rebellion covering a large part of the island. Most of central and east Java, and many of the pasisir (north coast) areas were affected. Two million Javanese, one third of the total population, were exposed to the ravages of war, one fourth of the cultivated area of Java sustained damage and about 200,000 Javanese died (Carey 1976:52 note 1). In securing their pyrrhic victory over the Javanese, the Dutch also suffered: as well as 7,000 Indonesian auxiliaries, 8,000 of their own troops perished and the war cost their exchequer an estimated 20 million guilders (De Graaf 1949:399). The end of the conflict left the Dutch in undisputed control of the island and a new phase of colonial rule began with the inception of Governor-General Johannes van den Bosch's 'cultivation system' (1830-1870). This proved immensely profitable for Holland. The war thus marked the end of a process, maturing since the period of Marshal Herman Willem Daendels (1808-1811), involving the change from the era of the Dutch East Indies Company, ${ }^{2}$ when contacts between Batavia and the south-central Javanese kingdoms had had the nature of ambassadorial links between sovereign states, to the 'high colonial' period when the Principalities occupied a clearly subordinate position to the European power.

This transition should be borne in mind by those who approach the early chapters of this book expecting the Dutch to loom large as the colonial masters of Java (Chapters I-IV). In the late eighteenth century, the island was not a Dutch version of the British Raj. A declining power in Europe, Holland seemed to be on its way out in Java while the south-central Javanese rulers enjoyed de facto sovereignty. The Fourth Anglo-Dutch War of 1780-1783 was the turning point for the Dutch as a colonial power. Faced with mounting debts, which peaked at 134 million guilders, the VOC was declared bankrupt and its assets taken over by the Dutch state on 1 January 1800 (Boxer 1979:101-2).

1 For the purpose of this volume, the term 'Indonesia' will be used to refer to the Netherlands Indies, and 'Indonesian' to the inhabitants of the archipelago. The colonial capital will, however, be referred to as 'Batavia' throughout rather than 'Jakarta'.

2 Vereenigde Oostindische Compagnie or VOC, 1602-1799, see Boxer 1979. 
Four years earlier control of the Dutch possessions in the East had been taken out of the hands of the Directors of the VOC, the so-called 'Heeren XVII' (Gentlemen 17), and vested in the new Committee for the Affairs of East Indies Trade and Colonies. ${ }^{3}$ The fact that during the international crises which led to the VOC's demise the governor-general and Council of the Indies in Batavia had to turn to the south-central Javanese rulers to help them to defend their colonial capital against possible foreign attack, illustrates the scale of the courts' military and political independence. Such requests for assistance occurred during the British attack in 1781, and again in 1793 when the Dutch Republic entered the War of the First Coalition (1792-1797) against France. ${ }^{4}$ Following the occupation of Holland by the French Army of the North in December 1794-January 1795, the Republic became a satellite of the grande nation. This had implications for Java. As one of Holland's overseas possessions, it was included in the policy announced by the exiled Dutch Stadhouder (head of state). This stated that the Republic's colonies should be handed over to the British to prevent them falling into the hands of the French. ${ }^{5}$ So began a twenty-year period in which Indonesia was drawn into the global conflict between Britain and France. Fought out during the Revolutionary (1792-1799) and Napoleonic Wars (1799-1802, 1803-1813, 1815) in Europe, the archipelago became a battle ground on land and sea. Between 1795 and 1797, British naval forces operating from Madras and Pulau Pinang captured most of the Dutch possessions outside Java. Although returned to Holland under the terms of the Peace of Amiens (1802), all were recaptured by the British in the seven years which followed the renewal of hostilities in Europe (May 1803) when Indonesia was placed under strict naval blockade. So tight was this interdiction that when Marshal Herman Willem Daendels received his appointment

3 Control was exercised first through the Batavian Republic's (1796-1806) Comité tot de Zaken van de Oost-Indische Handel en Bezittingen (Committee for the Affairs of East Indies Trade and Colonies) (1796-1800) and then through its Raad der Aziatische Bezittingen en Etablissementen (Board of Asiatic Possessions and Establishments) (1800-1806).

4 On the 1781 situation, see UBL, BPL 616, Port. 3 pt. 1, W.H. van IJsseldijk (Yogyakarta) to P.G. van Overstraten (Semarang), 8-10-1793. On the Dutch response to the sighting of French warships in the Sunda Straits in September 1793, see W.H. van IJsseldijk (Yogyakarta) to P.G. van Overstraten (Semarang), 28-9-1793, 5-10-1793, 8-10-1793, 30-10-1793 and 4-11-1793. Hamengkubuwana II had insisted that his 1,000 men should be considered as 'auxiliaries' (hulptroepen) not as mercenaries, even though they were being paid at the rate of four Spanish dollars a month per man by the VOC. In 1781, during the Fourth Anglo-Dutch War, the VOC had paid five Spanish dollars a month per head for Hamengkubuwana I's troops who were being kept on standby to defend the colonial capital against possible British attack.

5 The exiled Dutch Stadhouder (head of state), Prince William V of Orange (reigned 1766-1785 and 1787-1795), had sanctioned these British conquests through his so-called 'Kew letters'. Signed in his place of exile in England in February 1795, these ordered VOC officials to place the Company's possessions in Asia in British hands in order to prevent them falling to the French. 
as governor-general from Napoleon's younger brother Louis ${ }^{6}$ in January 1807, he was sent out to Java with a replacement governor-general, Rear-Admiral A.A. Buyskes, following on a separate fast frigate in case the marshal fell into British hands (Chapter V note 46). As we will see in Chapter V, the parlous financial and military situation of the Dutch was well understood by the south-central Javanese rulers. So much so that one senior former VOC official even suggested in 1808 after Daendels' arrival that the European government should employ some holy men and ascetics to make favourable prophecies on behalf of the Dutch to disguise their vulnerability. In the same year, an unusual event at one of the regular tiger and buffalo fights staged in honour of the visit of a high Dutch dignitary to the Yogyakarta court may have been interpreted as an indication that Holland would soon be placed hors de combat in terms of their rule in Java (Chapter V).

The tragedy for the Javanese was that just as all the signs seemed to be pointing in the direction of a Dutch collapse, half a world away in Europe events were taking place which would change the Javanese 'old order' for ever. The twin political and industrial revolutions then tearing the ancien régimes of eighteenth-century Europe apart would hit Java with the force of an Asian tsunami. In the space of just four years (1808-1812), the relationship between the European government ${ }^{7}$ and the south-central Javanese rulers was transformed. Yogya bore the brunt of these changes. In quick succession, the re-energised Franco-Dutch regime of Marshal Daendels (1808-1811) and the British-Indian administration of Thomas Stamford Raffles (1811-1816), forced open Yogya's eastern outlying territories (Chapter VI), plundered its court and exiled its reigning monarch (Chapter VII). After the fall of the kraton (fortified royal capital; court) in June 1812 and the imposition of new treaties, the relationship between Batavia and the princely states came to resemble that of the post-Plassey era in India when the British replaced the Mughal emperors in Lower Bengal (Chapter VIII). The returned Dutch administration of Governor-General G.A.G.Ph. van der Capellen (1816-1826) continued this process. Its desperate need for money

6 Louis Bonaparte had been installed by his elder brother as king of Holland, reigning from 1806 to 1810, when the former Batavian Republic was annexed to France, see Chapter VII.

7 Since there were so many changes of colonial regime involving different European powers (Dutch, British, French, Belgian) in the period covered in the present volume, it has been decided for the purposes of succinctness to refer to the colonial power in Batavia as the 'European government' throughout. The principle regimes which governed Java in the period 1785-1855 were: 1 . the Dutch East Indies Company (to 1796); 2. the Batavian Republic (1796-1806) through its two Committees (note 2); 3. the Franco-Dutch kingdom of King Louis of Holland (1806-1810) and the French Empire (1810-1813), when Holland was annexed to Napoleon I's France; 4. the British-Indian interregnum of lieutenant-governors T.S. Raffles and John Fendall (1811-1816), when Java was under the authority of the governor-general of India; 5 . the returned Dutch administration of the three commissionersgeneral G.A.G.Ph. van der Capellen, C.Th. Elout, and Rear Admiral A.A. Buyskes (1816-1818), who reported directly to the Director-General of Trade and Colonies (Johannes baron Goldberg, in office 1815-1818) of the new United Kingdom of the Netherlands (present-day Holland and Belgium) (1814-1830); and finally 6. the government of the Netherlands Indies (from January 1818), which from 1830 was under the direction of the Dutch crown and - from 1848 - the States-General. 
and lack of understanding of the effects of its policies on ordinary Javanese prepared the ground for the Java War (Chapter IX). Adverse environmental and health conditions, in particular the May 1821 cholera epidemic, coupled with soaring rice prices provided the triggers for the massive popular uprisings of July-August 1825 which heralded the outbreak of the Java War (Chapter X).

For the Javanese, this five-year conflict had far-reaching implications: for perhaps the first time a rebellion had broken out at one of the south-central Javanese kraton which had at its heart social and economic grievances rather than dynastic ambitions. The emergence of a strong charismatic leader in the person of Pangéran Dipanagara (1785-1855), who took the title of the Javanese messianic Ratu Adil ('Just King'), served to bring many disparate social elements under the single banner of Javanese Islam. Widespread millenarian expectations caught the imagination of the peasantry and acted as a catalyst for social and economic grievances, accumulating since the beginning of the nineteenth century. The concept of holy war (prang sabil), imagery from the Javanese shadow-play (wayang), and Javanese nativist sentiments, made up of an intense longing for the restoration of an idealized traditional order - which Dipanagara described as 'restoring the high state of the Islamic religion in Java' 8 - all helped to forge a common identity amongst the prince's followers. In this fashion, nobles, dismissed provincial officials, religious teachers, professional bandits, porters, day labourers, tax-paying farmers (sikep) and artisans were brought together briefly in a common cause (Chapter XI). The Java War was thus of immense significance for Indonesia's future. The subtle interplay of economic grievances and millenarian hopes created a movement of unique social breadth which in some respects anticipated the nationalist movement of the early twentieth century (Carey 1976:52-3). These nationalist antecedents were noted by F.G. Valck (1799-1842), a senior Dutch official who served in a number of residency postings in south-central Java during the two decades which spanned the Java War and its immediate aftermath (Christiaans 1992-93:129-30). Writing in 1840, he observed:

[My] nearly twenty years of administrative service in various Residencies has taught me that the spirit of the ordinary Javanese is against us, not because we Netherlanders treat him badly but because he is imbued with a feeling of nationality [...]. Despite all the benefits which he gets from us, he cannot suppress the wish to be governed by his own rulers and chiefs even though they would administer him worse [than we would] [...]. He continues to see in us foreign tyrants, who in morals, customs, religion and clothing etc differ so much from his own [...]. The sight of every European reminds him of his humiliating situation [and] he cannot refrain from giving him looks of hatred or contempt whenever he feels he can get away with it without incurring punishment. ${ }^{9}$

8 The Javanese phrase used by Dipanagara and his supporters was: mangun luhuripun agami Islam wonten ing Tanah Jawi sedaya, see Carey 1974b:285.

9 Dj.Br. 18, F.G. Valck, 'Geheime memorie behoorende bij het algemeen verslag der residentie 
Valck's views were not alone. Acute observers like the lawyer, Willem van Hogendorp, who served as a senior official in Commissioner-General L.P.J. du Bus de Gisignies' administration (1826-1830) during the Java War (De Prins 2002:113), confided similar misgivings in his correspondence with his father, ${ }^{10}$ in 1827-1829 (Van Hogendorp 1913:170):

It is not the war as such or the number of our enemies which constitutes my greatest concern about Java and our rule here [...] but it is the spirit of the whole population of Java from one end to the other, and I include here the spirit of [the inhabitants of] our most important outer island possessions in Borneo, Makassar and throughout Sumatra [...]. They are tired of us.

This strand of anti-Dutch 'nationalism', if such it can be called at this early date, will be explored more fully in the chapter which deals in detail on the Java War (Chapter XI).

The cultural dislocation wrought by the impact of the new European imperialism of the early nineteenth century on south-central Java is one of the key themes of this book. It also seeks to explain events through the eyes of its central protagonist, Dipanagara. A key transitional figure, he lived through the shift from the old order of late eighteenth century Java to the new 'high colonial' era based on the twin political and industrial revolutions which were transforming Europe in his lifetime. In many ways a traditional figure steeped in the values of pre-modern Java, particularly the world of the southcentral Javanese courts, Dipanagara also pointed to the future. One thinks here of his use of Javanese Islam, particularly its millenarian traditions, as a way of forging a new identity for Javanese Muslims in an era when the old Javanese order was crumbling. Dipanagara lived in a world increasingly divided between those who were prepared to accommodate themselves to the new European dispensation and those who saw the Islamic moral order (agami Islam) as the lodestar in a society which had lost its traditional moor-

Djocjocarta over het jaar 1839' (henceforth: Valck, 'Geheime memorie'), 31-3-1840. Valck was a fluent Javanese speaker who had served in postings in central Java since the 1820s and had fallen in love with Hamengkubuwana V's favourite unofficial wife (selir) whom he had taken as his young mistress (Houben 1994:109). His knowledge of Javanese society was thus personal as well as administrative. His rather convoluted Dutch text reads: Het bijna twintig jarig bestuur van onderscheidene residentiën heeft mij geleerd dat de geest van den gemeenen Javaan tegen ons is, niet omdat wij Nederlanders hem niet goed behandelen maar omdat hij met gevoel van nationaliteit bezield is, en omdat alle der voordeelen die hij van ons erlangd, den wensch bij hem niet kunnen onderdrukken om door zijne eigene vorsten en hoofden alware zulks slechter geregeerd te worden, terwijl hij in ons steeds vreemde overheersers ziet die in zeden, gewoonten, Godsdienst, kleding enz. zoo zeer van de zijnen verschillen dat hij aan zijne vernederende toestand bij het aanschouwen van iederen Europeaan herinnerd wordt en dan ook niet nalaat om hem blijken van haat en minachting te geven wanneer hij zulks slechts ongestraft vermeend te kunnen doen.

10 This was Gijsbert Karel van Hogendorp (1762-1834). One of the founders of the kingdom of the United Netherlands (1815-1830), he exercised a significant influence on the development of Dutch colonial policy during the reign of King William I (reigned 1813-1840) (Prins 2002:45-6, 185-6). 
ings. The Java War gave impetus to a process which is still working itself out in modern Indonesian society today: namely, the integration of Islamic values into contemporary Javanese and Indonesian identity. Dipanagara's world view also came to encompass a distinctly contemporary concern with how Javanese Muslims should live in an age of Western imperial domination. For Dipanagara, unlike present-day Indonesian Muslims, the answer seemed to lie in the waging of holy war and the development of a clear distinction, which developed during his five-year struggle, between the wong Islam ('people of Islam'; Muslim believers), the European kapir laknatullah (heretics accursed by Allah), and the Javanese kapir murtad (apostates; Javanese who had allied themselves with the Dutch). But there was also a deep concern on the prince's part for the preservation of specifically Javanese values as expressed in language, dress and cultural codes which can be seen most clearly in his treatment of Dutch prisoners during the Java War. We will see in the chapter on the war (Chapter XI), how they were expected to adopt Javanese dress and speak to their captors not in the reviled language of the new colonial state - 'service Malay'11 - but in High Javanese (krama), the medium of the court elite. Despite his adoption of Ottoman dress and titles such as 'Ali Basah' ('The High Pasha') for his military commanders (Chapter III), Dipanagara was no Islamic reformer. Instead, he was a traditional Javanese Muslim for whom there was no inherent conflict between the spirit world of Java, and membership of the international ummat (community of Muslim believers) and its spiritual and politico-cultural centres in the Hejaz (present-day Saudi Arabia) and Ottoman Turkey. Dipanagara did not prevail in achieving his goal of restoring the high state of the Islamic religion in Java. Indeed, the dignity and integrity which he fought for on behalf of the Javanese ummat would only be achieved in outward form ninety years after his death with the declaration of political independence from the Dutch in 1945. His wider moral vision of securing an honoured place for Islam in the life of the nation, however, is still being negotiated at a time of unprecedented global conflict between what the Islamic community see as the 'materialistic' values of the West and the fissiparous loyalties of the worldwide Muslim ummat.

In any other culture, such a key figure would have been the subject of numerous biographies and historical studies. Every aspect of Dipanagara's life would have been researched in detail, his understanding of Islam and of his Javanese inheritance the subject of weighty monographs. Indeed, one might have expected that his own writings, in particular his impressive autobiography written while in exile in Manado (1830-1833), the Babad Dipanagara, which runs to over 1,000 pages in manuscript, would have long since appeared in a copiously annotated modern text edition. The situation is unfortunately very different. History seems to have little honour in present-day Indonesia and

On this Dienstmaleisch, see Hoffman 1979:65-92. 
the results of this have been painfully evident in Jakarta's abysmal handling of its East Timor adventure (1975-1999) and its belated understanding of the particular society, politics and culture of Aceh. There is little money for research or government funds - let alone the scholarly attention and respect needed - for the preservation of manuscripts. The result is that the original pégon (unvocalised Arabic script Javanese) copy of Dipanagara's babad in the National Library - equivalent to Oliver Cromwell's common place book or George Washington's diary - is crumbling to dust (Carey 1981a:lix-lx note 76). As for the voluminous Dutch Residency reports in the Indonesian National Archives (Arsip Nasional), the backbone of the present study, who can be bothered to use them today? The result is an historiographical void. It is as though the clock stopped at the time when the Dutch military historians P.J.F. Louw and E.S. de Klerck completed their magisterial six-volume work on the Java War (Louw and De Klerck 1894-1909) or the Rusche edition (1908-09) of the Babad Dipanagara was published in Batavia before the First World War. Indeed, since independence in 1945, only a handful of studies have appeared in Indonesian: one thinks here of Yamin (1950), Tanojo (n.y.), Soekanto (1951a, 1952), Sagimun (1965), and Djamhari (2003). These have all afforded access to aspects of Dipanagara's life and times to a post-independence Indonesian readership, but apart from the last, which is primarily a history of the Dutch bentheng stelsel (system of fortified strong points) in the last three years of the Java War, none have been based on primary research.

The present study should have appeared thirty years ago in the immediate aftermath of its acceptance as a doctoral thesis at the University of Oxford (1975). At that time, on the recommendation of the late Professor M.A.P. Meilink-Roelofsz, the thesis manuscript was accepted as the basis for a monograph publication in the 'Verhandelingen' series of the Koninklijk Instituut voor Taal-, Land en Volkenkunde (KITLV, Royal Institute of Southeast Asian and Caribbean Studies) in Leiden. But Professor Meilink-Roelofsz made three important recommendations which were in fact conditions needing to be met before publication could proceed: first, that the text edition of the Surakarta version of the Babad Dipanagara with its extensive annotations, and the thesis preface, which dealt primarily with the Javanese sources for the early nineteenth-century history of Yogyakarta, should be published separately; second, that much more attention should be paid to the social and economic origins of the Java War. In particular, she urged that I investigate further the role of the Chinese in south-central Java and the economic relations between Javanese and Europeans, as well as the workings of the Javanese apanage system. Third, she recommended that the entire structure of the thesis should be recast to allow for shorter chapters and greater thematic coherence. These three conditions were all valid, but they constituted a considerable challenge involving extensive additional research just at a time when I was embarking on 
an academic career in the University of Oxford teaching British and European history. In 1976-1977 and 1978, however, before my teaching duties began in earnest with my tutorial Fellowship at Trinity College, I was able to carry out some important further research at the Arsip Nasional in Jakarta by kind permission of the former Director, Dra Soemartini and her staff, in particular the late Pak Sundoyo whose knowledge of the Dutch East Indies colonial archive never failed me. During this period of fieldwork, the British Academy supported me through the provision of a British Academy Travelling Fellowship in Southeast Asia (1976-1977). The bulk of the Dutch archive material used in this study, in particular the letters in the Residency archive of Yogyakarta preserved in the Arsip Nasional, were gathered in that period (Carey 1978). At the same time, the British Academy's Oriental Documents Committee tasked me with preparing a text edition (Carey 1980; Carey and Hoadley 2000) of all the documents of a non-literary nature collected by the scholar-administrator John Crawfurd, and his close associates in the British administration of Java (1811-1816), Lieutenant-Governor Thomas Stamford Raffles (in office 1811-1816) and Colonel Colin Mackenzie, surveyor-general of Madras and chief engineer officer to the British invasion force. These documents derived in the main from the plundered archive of Yogyakarta (Chapter VIII). This allowed me to meet two of Professor Meilink-Roelofsz's conditions: namely, the publication of the Surakarta version of the Babad Dipanagara (Carey 1981a), and the elucidation of the social and economic background to the Java War (Carey 1986, 1997). I still struggled, however, to meet Professor Meilink-Roelofsz's third and perhaps most important condition: namely, to recast the whole work in a more readily accessible format with shorter chapters and greater thematic coherence. This daunted me for the best part of twenty-five years from the early 1980s. During that time, I was also involved in researching and publishing on a much more present-day concern, namely, the Indonesian occupation (1975-1999) of the former Portuguese colony of East Timor (now the Democratic Republic of TimorLeste). It has only been since Timor-Leste's independence in 2002, and in particular during a recent six-month period of sabbatical leave (2006), that I have been able to give my undivided attention to recasting and rewriting my original thesis for the purposes of the present publication. Although a considerable amount of new material has been added and the format and chapter headings of the present volume differ considerably from that of my 1975 Oxford dissertation, I have not had the opportunity to conduct sustained research on the period of the Java War itself. There are literally thousands of letters in the General State Archives in The Hague which deal with the conduct of the war, some of which contain important Javanese material. The private collection of the former Dutch commander, Lieutenant-General Hendrik Merkus de Kock (1779-1845), alone could be the basis for a new study of the conflict, as could the numerous Javanese and Malay letters in the De Renesse-Breidbach family archive in the 
Algemeen Rijksarchief in Brussels, which contains most of the correspondence of Burggraaf L.P.J. du Bus de Gisignies during his period as commissionergeneral of the Netherlands-Indies (1826-1830) (De Prins 2002:262). The French historian Henri Chambert-Loir's work on the 600-page war diary of Du Bus' fellow Belgian, Comte Édouard Errembault de Dudzeele (1789-1830), has also opened up a new and highly personal insight into the life of an infantry captain on the Dutch side during the war (Chambert-Loir 2000:267-300). Since fully two-thirds of Dipanagara's own published autobiography is devoted to the war years (Rusche 1908-09), there is clearly scope for a new analysis of this crucial colonial conflict which could draw on both Dutch and Javanese sources. But I am not a military historian and my focus has remained throughout on the political and economic history of pre-1825 Yogyakarta as well as on Dipanagara's own life history until his death in exile in Makassar in January 1855. Louw and De Klerck's magnum opus together with the numerous books on the Java War in Dutch as well as Djamhari's recent Indonesian publication (Djamhari 2003), all make the five years of the war the most extensively researched period of the prince's life. It thus seemed otiose to attempt a new survey of such a comparatively well studied topic. But I recognise that some readers may still consider a study of Dipanagara without a detailed chapter on the Java War as a bit like Hamlet without the Prince of Denmark. If so, then there will clearly be scope either for a second volume or an updated and revised second edition of this work in which greater space is given to the war itself. A new study will also need to be made of the original pégon manuscript of Dipanagara's autobiographical babad in the A.B. Cohen Stuart collection in the Musium Nasional in Jakarta (Carey 1981a:xxv, lix-lx note 76).

Another consideration for not embarking on new research at this stage has been the need to get this book out in time for the 2008 Research Assessment Exercise (RAE). This UK Government Higher Education Funding Council body grades every Faculty in the country every seven years according to their publication record and research output. At the last RAE in 2001 Oxford History Faculty famously scored only a 5, compared to its much smaller former polytechnic rival, Oxford Brookes, which achieved a coveted $5^{*}$. Since there is a 31 December 2007 cut-off point for the next RAE, I have been under considerable pressure to complete on time. In a sense, the RAE assessors should be recognised as the immediate inceptors of this publication and I owe them thanks, as well as my RAE adviser in the History Faculty, Professor Richard Carwardine, and the Faculty chairman, Dr Christopher Haigh, for forcing me to see a long-delayed research project through to the publication stage. But I must also acknowledge here many other even more important debts. First and foremost to the KITLV Press, in the person of its principal commissioning editor for the 'Verhandelingen' series, Dr Harry Poeze, for having stood by me all these years and kept the opportunity for publication 
open. Wat in het vat zit, verzuurt niet ('what sits in the vat, never goes sour') was his own pithy comment when he learnt that after twenty-five years of constant postponement, I might at last be serious about getting something into print. I would also like to thank the marvellous editorial team of the KITLV Press, Kees Waterman, Bregtje Knaap, Marjan Groen, and Dan Vennix, who saw a monstrous manuscript into print.

Second, I am grateful to Professor Merle Ricklefs, now of the National University of Singapore, for having acted as my informal supervisor when my thesis was first written in 1974-1975, and then having continued to inspire me with his remarkable flow of works on the history of seventeenthand eighteenth-century Java, most recently on the process of Islamisation since the fourteenth century (Ricklefs 2006). Third, I owe a considerable obligation to the late Kangjeng Radèn Tumenggung Puspaningrat, sometime wedana of Bantul, who undertook all the preliminary transliterations of the Javanese documents and chronicles which I have used for my work. It was also thanks to Pak Puspaningrat that I was put in touch with Pak Sastrasuganda of Daengan Lor in Yogyakarta who transliterated all the Javanese texts in pégon script. These included the two volumes of Dipanagara's Makassar manuscripts dealing with the history of Java and Javanese legends and his own disquisitions on Islam, as well as the proclamation from Kyai Iman Sampurna which I discuss in Chapter IX. Such relationships between Western scholars and Javanese scribe-informants have not always been a happy one: in the days of Raffles and Crawfurd and the subsequent 'high colonial' period in Java (1830-1942), it was often downright exploitative. I trust that it has not been so in this case.

In Leiden, I was privileged to receive help and encouragement from a distinguished older generation of Dutch scholars of Java, amongst them Professor C.C. Bergt, Dr Th.G.Th. Pigeaudt, Professor G.W.J. Drewest, Dr H.J. de Graaft, Dr B.J. Bolandt, Rob Nieuwenhuyst, and Dr J. Noorduynt, as well as those who have only recently retired such as Professor Cees Fasseur, or are currently in post such as Professor Leonard Blussé, Dr Dick van der Meij (Leiden University/Universitas Islam Negeri Syarif Hidayatullah, Jakarta), and Professor Vincent Houben (now of the Humboldt University of Berlin). Besides having the thankless task of reading through my original manuscript, Professor Meilink-Roelofsz was also quite extraordinarily helpful as head of the Tweede Afdeeling of the Algemeen Rijksarchief (now Nationaal Archief, General State Archives) in opening out to me the vast resources of their colonial collections, as were her colleagues Mr M.G.H.A. de Graaf and Francien van Anrooij. The bibliographic treasures of the KITLV were made available courtesy of Dr E. van Donzel, acting head of the KITLV when I returned from my first period of fieldwork in Indonesia in June 1973, and by F.G.P. Jaquet + and Dorothée Buur, both of whom greatly extended my knowledge of Dutch colonial life and literature. At the same time, the incomparable Javanese ma- 
nuscript holdings of the Universiteits Bibliotheek in Leiden were facilitated through the former adiutor interpretis of the Legatum Warnerianum, Dr R. Roolvinkt and Mrs E.M.L. Andriessen-Lückt, to both of whom go my sincere thanks. In Indonesia in 1971-1973, I was honoured to receive the assistance and cooperation of His Royal Highness, the late S.D.I.S. Kangjeng Sultan Hamengkubuwana IX, who made available to me the historical resources of his court. His Royal Highness Bendara Pangéran Harya Poeroebojo, Drs Mudjanattistomo, and Kangjeng Radèn Tumenggung Widyakusuma, all now deceased, also enabled me access to certain manuscripts in the Widya Budaya (Yogya kraton) library, and in Drs Mudjanattistomo's case taught me Javanese. While in Yogyakarta and Jakarta, I also received important assistance from Professor Stuart Robson, Professor P.J. Zoetmulder S.J.t, G.J. ('Han') Resinkt, Professor Sartono Kartodirdjot, Aji Damais and Dr Onghokhamt.

Professor Oliver Wolterst, Professor Ben Anderson, and Professor George McT. Kahint of Cornell University were the first to open my eyes to the possibility of becoming an historian of Southeast Asia during an unforgettable year spent at Cornell University (1969-1970). It is an honour to be able to acknowledge my debt to them here.

My research in England, the Netherlands and Indonesia from 1970-1978 was made possible by generous support from the aforementioned British Academy fellowship, as well as the UK Social Science Research Council and the British Council. The Bryce and Arnold Funds of the Modern History Faculty at Oxford enabled me to employ the exceedingly talented Dr Soe Tjen Marching, a scholar of modern Indonesian literature, as my research assistant in transferring all the appendices onto computer-text format, as well as seeing that the entire manuscript was read through by an expert copy editor, Michael Perrott. Trinity College, Oxford, sustained me as a graduate student when I was conducting my initial historical research in the Netherlands and Indonesia in 1970-1973, and Magdalen College, Oxford subsequently gave me a Prize Fellowship (1974-1979) which supported the writing up of the subsequent Jakarta archive materials. The present book was finished in the spacious beauty of the Sléibh Bearna mountains in rural East Clare in the former county constituency of Ireland's independence heroes, Daniel O'Connell and Eamon de Valera, during the long dry summer of 2006, as good a place as any to contemplate the passing of colonial regimes, the fate of born leaders in changed times, and the abiding influence of the past on humanity's increasingly uncertain future. It is being published exactly 200 years after Marshal Daendels set foot in Batavia to begin what Dipanagara had been warned by a disembodied voice heard while sleeping at Parangkusuma during his circa 1805 pilgrimage to the south coast of Java would mark 'the beginning of the ruin of the Land of Java' (Chapter IV). That prophecy, whose accuracy would be startlingly fulfilled in the following years of Franco-Dutch (1808-1811), British (1811-1816) and 
post-1816 Dutch rule, has suggested the title of the present volume.

For the encouragement, advice, criticisms and unstinting support of all those named above I shall always be grateful. That this preface resembles a First World War battlefield in the sheer number of crosses for the deceased indicates that a whole generation of scholars, archivists and librarians has passed on before they could even be properly thanked for their assistance through the presentation of a copy of this volume. I hope I have done justice to their memory. Those who read this book should realise that I stand on the shoulders of giants. My own shortcomings, particularly in the field of military history, remain all too obvious. For these I beg your indulgence. Nuwun pangapunten gunging pangaksami!

\section{Preface to Second Edition}

A bare four months has elapsed since the first edition of this book was launched at the KITLV in Leiden on 19 December 2007 with a celebratory glass of Dipanagara's favourite South African white Constantia wine. A second edition then seemed a distant prospect. A volume of 964 pages on Indonesia's national hero hardly seemed destined to be a bestseller. Yet so it has proved.

Unfortunately, time has not permitted a detailed revision of the text beyond correcting some infelicities of style, adding a few more cross-references and replacing two of the maps (xxvi-xxx) and one of the illustrations (Plate 31). Two reviewers, Roy Jordaan and Amrit Gomperts, kindly suggested some small improvements. Cornelis P. Briët, sometime judge of the Joint High Court of Justice of the Netherlands Antilles and Aruba, now researching a history of the Supreme Court of the Dutch East Indies (1819-1849) and of the Rijck van Prehn affair (1819), also shared with me his impressive knowledge of the genealogical and family histories of early nineteenth-century VOC and Dutch East Indies personnel. The corrections in this second edition to the dates and names of these officials owe much to his expert guidance. Readers who would like to know more about the protracted genesis of the present book and my original interest in its stormy petrel protagonist can read an interview in Itinerario, the Bulletin of the Leiden Centre for the History of European Expansion, conducted by Leonard Blussé at the time of the original book launch (Itinerario 2008:7-18). This adds some personal details to what I outlined briefly in the preface to the first edition.

I wish to place on record once again my continuing appreciation for the support of the KITLV Press director, Harry Poeze, and his brilliant editorial team, in particular Kees Waterman and Dan Vennix.

Matur nuwun sèwu! 


\section{Abbreviations}

\begin{tabular}{|c|c|}
\hline $\mathrm{AD}$ & Anno Domini, the Christian era \\
\hline $\mathrm{AH}$ & Anno Hijrae, the Muslim era \\
\hline AJ & Anno Javano, the Javanese era \\
\hline AN & Arsip Nasional Republik Indonesia, Jakarta \\
\hline AvJ & Archief van Jogja (KITLV H 698a-b, 699, Rouffaer collection) \\
\hline AvS & Archief van Soerakarta (KITLV H 698a-b, Rouffaer collection) \\
\hline BD (Manado) & Babad Dipanagara (Manado version), LOr 6547 a-d, 4 vols \\
\hline B.Ng. & Babad Ngayogyakarta. Sana Budaya MSS. A135 A136, A144, 3 vols \\
\hline Baud & J.C. Baud private collection (Nationaal Archief, The Hague) \\
\hline BL Add. & British Library (London) Additional manuscript \\
\hline BPL & $\begin{array}{l}\text { Bibliotheca Publica Latina (Western language MS in } \\
\text { the Leiden Universiteits Bibliotheek) }\end{array}$ \\
\hline Dfl. & $\begin{array}{l}\text { Dutch florin (Generaliteits gulden containing } 9.61 \text { grams of } \\
\text { fine silver, see also sub: } f \text { below) }\end{array}$ \\
\hline Dj.Br. & $\begin{array}{l}\text { 'Bundel Djokjo Brieven' (volume of letters in the Yogyakarta } \\
\text { Residency archive, Arsip Nasional, Jakarta) }\end{array}$ \\
\hline $\mathrm{dK}$ & $\begin{array}{l}\text { H.M. de Kock private collection (Nationaal Archief, } \\
\text { The Hague) }\end{array}$ \\
\hline Du Bus & $\begin{array}{l}\text { L.P.J. du Bus de Gisignies private collection (Nationaal } \\
\text { Archief, The Hague) }\end{array}$ \\
\hline Eur. & Raffles European MS (British Library) \\
\hline$f$ & $\begin{array}{l}\text { Dutch East Indies florin (Indische gulden/Java rupee) } \\
\text { containing } 10.91 \text { grams of fine silver, which, until 1826, when } \\
\text { the Dutch guilder ( } D \text { fl.) became the standard coin in Indonesia, } \\
\text { was exchanged at an agio of 1:1.25 against guilders minted } \\
\text { in Holland }\end{array}$ \\
\hline GG & Governor-General of the Netherlands Indies \\
\hline GKA & Geheim en Kabinets Archief (Nationaal Archief, The Hague) \\
\hline IOL & India Office Library (British Library, London) \\
\hline IOR & India Office Records (British Library, London) \\
\hline Jav. & Javanese \\
\hline Java NOK & $\begin{array}{l}\text { 'Java's Noord Oost Kust' (volumes of letters in the archive of } \\
\text { the government of Java's Northeast Coast, Arsip } \\
\text { Nasional, Jakarta). }\end{array}$ \\
\hline J.r. & Java rupee (see also sub: $f$ above) \\
\hline Kab. Miss. & $\begin{array}{l}\text { Kabinet Missive (Algemeene Secretarie archive, } \\
\text { Arsip Nasional, Jakarta) }\end{array}$ \\
\hline KGPAA & Kangjeng Gusti Pangéran Aria Adipati \\
\hline KITLV & Koninklijk Instituut voor Taal-, Land- en Volkenkunde (Leiden) \\
\hline
\end{tabular}


KITLV H Western language MS $(\mathrm{H}=$ Hollands $)$ in the library of the Koninklijk Instituut voor Taal-, Land- en Volkenkunde, Leiden KITLV Or Oriental language MS in the library of the Koninklijk Instituut voor Taal-, Land- en Volkenkunde, Leiden

Knoerle 'Journal' J.H. Knoerle, 'Aanteekeningen gehouden door den 2e Luit Knoerle betreffende de dagelyksche verkeering van dien officer met den Prins van Djocjakarta, Diepo Negoro, gedurende eene reis van Batavia naar Menado, het exil van den genoemden Prins', Manado, 20-6-1830. MS 391 of the Johannes van den Bosch private collection in the Nationaal Archief, The Hague LOr Leiden University Library Oriental MS.

Mack.Pr. Colonel Colin Mackenzie private collection (India Office Records, British Library, London)

MvK Ministerie van Koloniën (Ministry of the Colonies archive in the Nationaal Archief, the Hague)

NA Nationaal Archief (General State Archives), The Hague

NBS Netherlands Bible Society (Nederlands Bijbelgenootschap) manuscript, Leiden University Library

NvB H.G. Nahuys van Burgst private collection (BPL 616, Leiden University Library)

P. Pangéran

Port. Portfolio (Nahuys van Burgst private collection)

pt. part

r.r. $\quad$ ronde real (worth about $D f l .2 .80$ )

R. Radèn

R.A. Radèn Ayu

RAI Royal Artillery Institution (London)

RAS Royal Asiatic Society (London)

R.Ng. Radèn Ngabèhi

R.T. Radèn Tumenggung

Sal. Kadanoerejan Serat Salasilah para loeloehoer ing Kadanoerejan. Panti Budaya (Sana Budaya Museum, Yogyakarta) MS B. 29

SB Sana Budaya Museum manuscript (Yogyakarta)

S.Br. 'Bundel Solo Brieven' (volumes of letters in the Surakarta Residency archive of the Arsip Nasional, Jakarta)

Schneither G.J.Chr. Schneither private collection (Nationaal Archief, The Hague)

Sp.D. Spanish dollar (worth about Dfl. 2.56)

vAE Van Alphen-Engelhard private collection (Nationaal Archief, The Hague)

Valck, 'Overzigt' F.G. Valck, 'Overzigt der voornaamste gebeurtenissen in het Djokjokartasche rijk sedert dezelfs stichting in den jare 1755 tot aan het einde van den door de opstand van den Pangeran Ario Dhipo-Negoro verwekten oorlog in den jaren 1825 tot en met $1830^{\prime}, 1-8-1833$. MS in Dj.Br. 9A (and 1919) of the Arsip Nasional, Jakarta

VOC Vereenigde Oostindische Compagnie (Dutch East Indies Company, 1602-1799).

VROA Verslag omtrent 's-Rijks Oude Archieven 


\section{Maps of central and east Java}




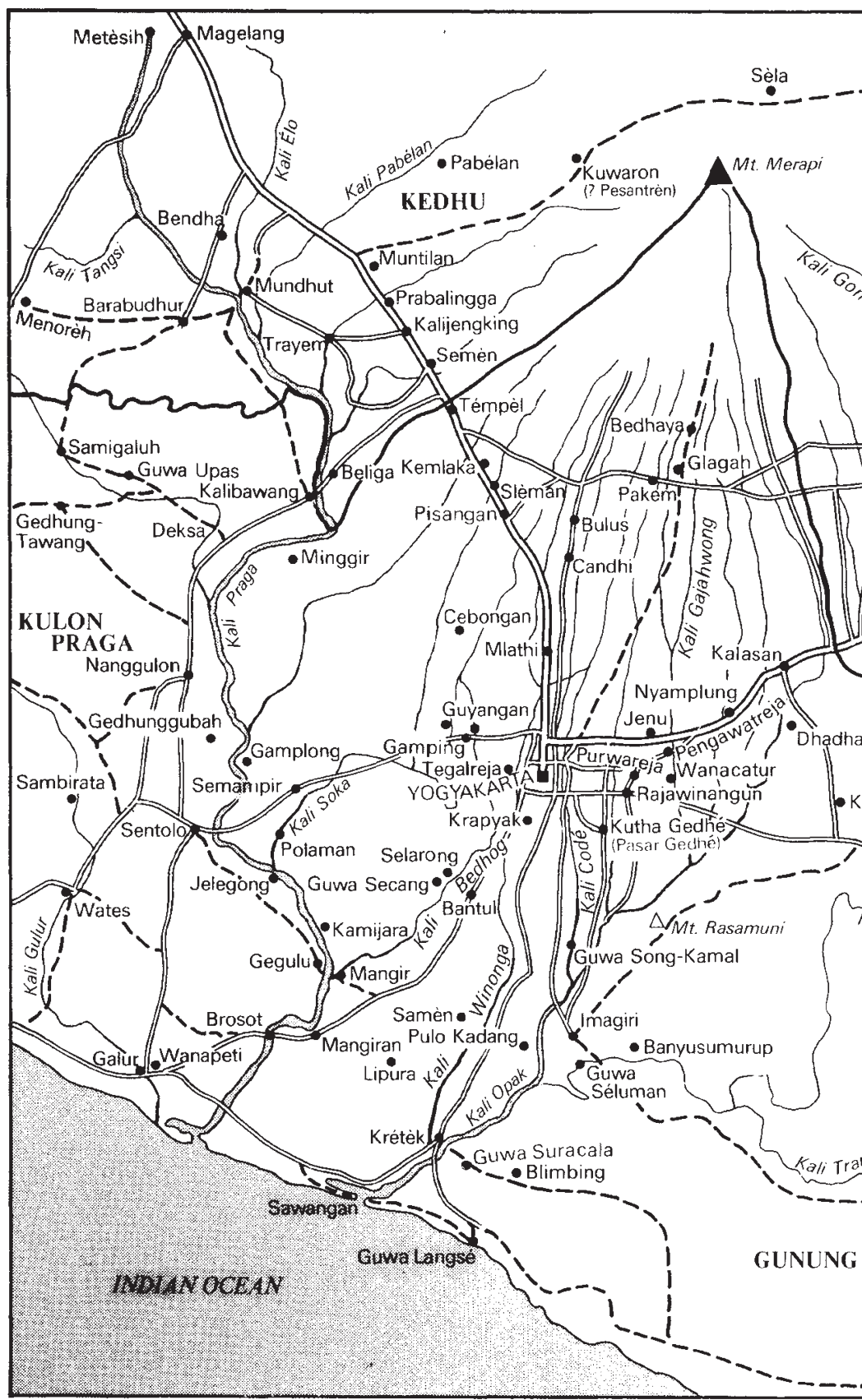

Map of the Yogyakarta area in the early nineteenth century showing Louw and De Klerck, IV: 1894-1909, adapted by J. Wilbur Wright of 


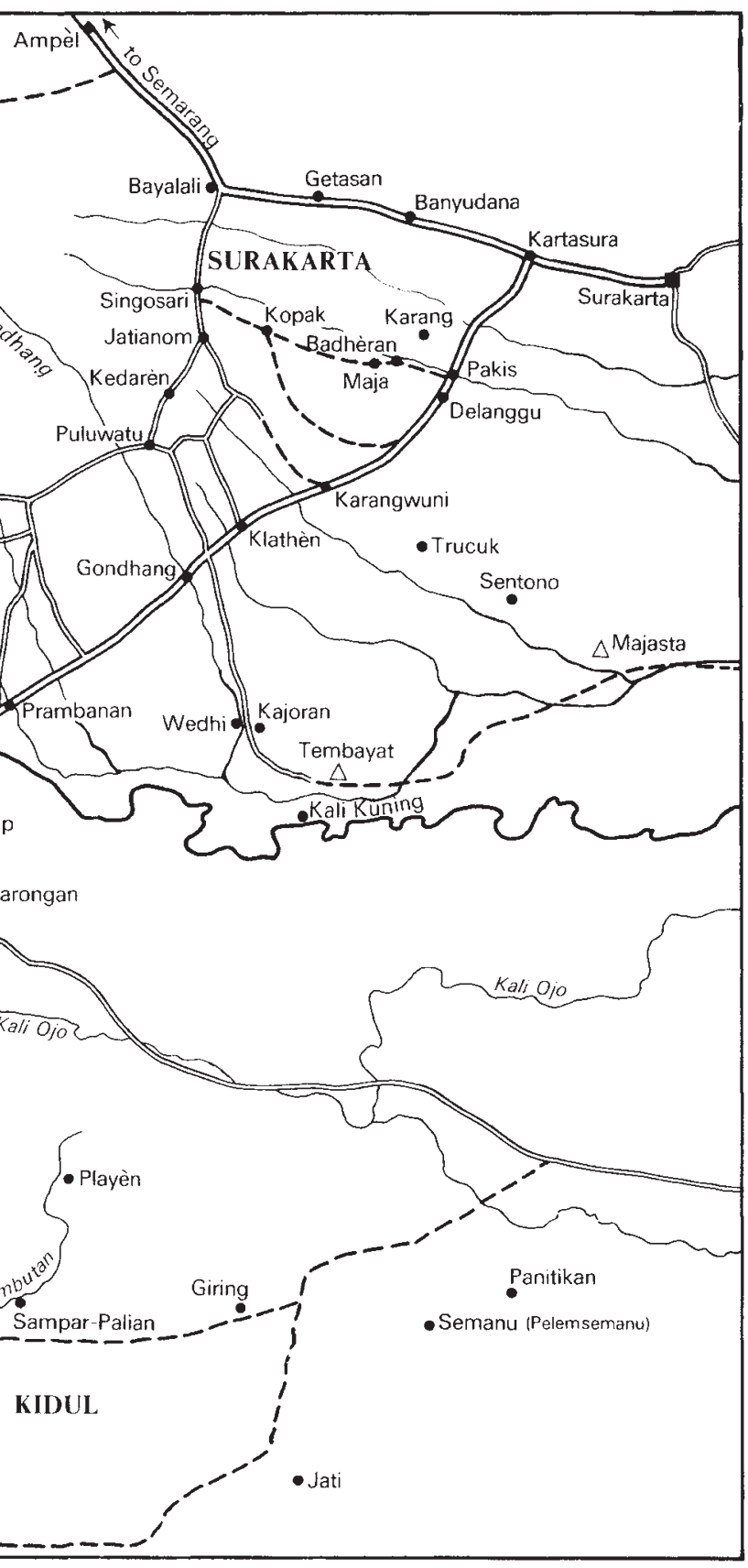

the main roads and villages. Map outline taken from xford. 


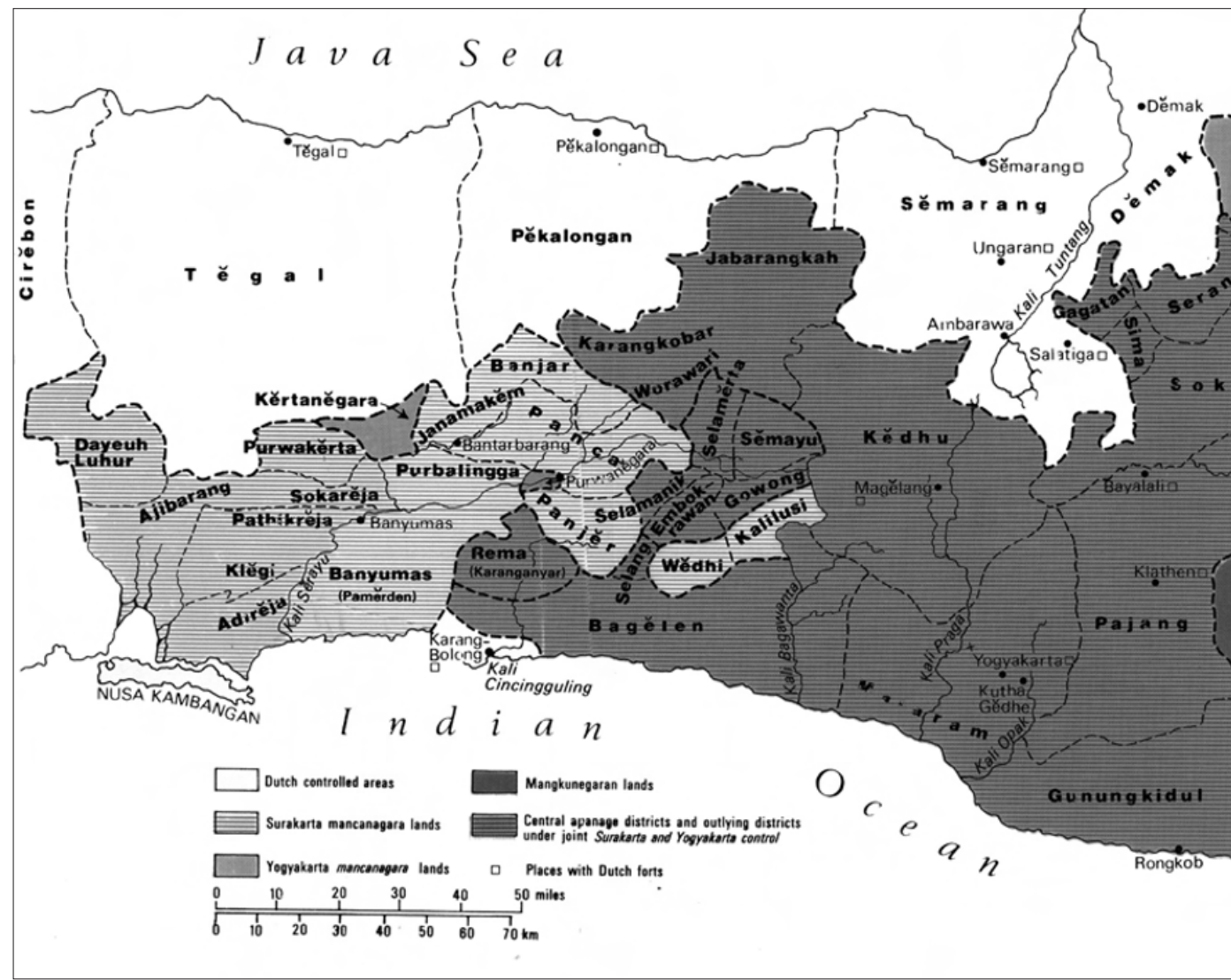

Map of central and east Java showing the apanage provinces belonging to the central Javanese adapted by J. Wilbur Wright of Oxford. 


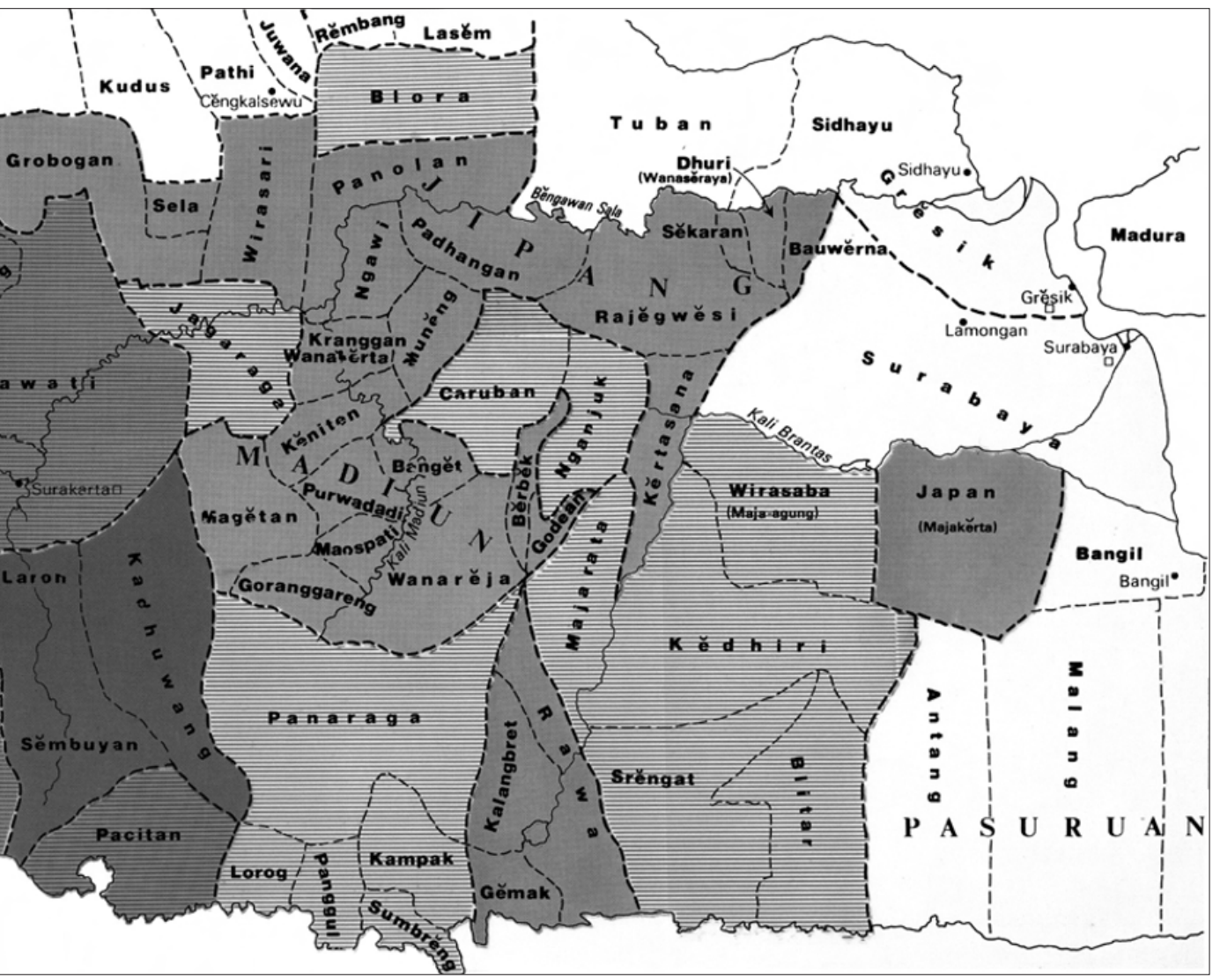

courts pre-1811. Map outline taken from Louw and De Klerck,VI: 1894-1909, 